\title{
ACCESS TO RURAL BANK CREDIT IN GHANA \\ The Case of Women Farmers in the Upper East Region
}

\author{
M. A. AKUDUGU \\ Centre for Continuing Education and Interdisciplinary Research (CCEIR) \\ University for Development Studies (UDS), Tamale - Ghana \\ Email: macmoudan@yahoo.com
}

IRENE S. EGYIR

Department of Agricultural Economics and Agribusiness

University of Ghana, Legon - Ghana

and

AKWASI MENSAH-BONSU

Department of Agricultural Economics and Agribusiness

University of Ghana, Legon - Ghana

\begin{abstract}
Credit is an effective tool that can be used to turn life around for a person, a family or transform self-image, unlock potential and boost the productivity and well-being of the poor. This paper examines the extent of women farmers' access to credit from Rural Banks (RBs) in the Upper East Region of Ghana. Data were collected from randomly sampled 200 women farmers from four districts and from the archives of the RBs in the region. Semi-structured questionnaire, focus group discussions and key informant interviews were used for data collection. Growth rates of credit supplies and factors influencing women farmers' credit access were estimated. The results of the empirical study revealed that the growth rate of credit supply by the RBs from 1998 to 2007 was about 18 percent per annum. Besides, credit supply to women grew at a lesser rate $(18 \%)$ than that of men (19\%) during the period. Factors influencing women farmers' extent of credit access were found to be age, interest rates, farm size, association membership and formal education, among others. Hence, it is recommended that credit supply to women should be improved if the MDGs, particularly those on poverty and hunger reduction as well as gender equality and empowerment are to be attained.
\end{abstract}

Key Words: Credit, Rural Banks, Supply Growth Rate, Poverty Reduction, Women Farmers

\section{Introduction}

Women throughout the world especially those in rural areas of developing countries have been said to have less command over productive resources. It has been demonstrated in development literature that rural women are more restricted in their access to and control over resources such as land and capital and in the type of entrepreneurial activities in which they can engage given their household roles and social norms (Fletschner and Carter 2008). One of the reasons identified as a determinant of women's access to and control over resources such as credit is creditworthiness (Nathan et al, 2004).

Creditworthiness is a critical factor because it helps borrowers take advantage of financial services provided by lenders. In Ghana, as elsewhere when women have tended to lack the agents and forces 
that determine credit worthiness, group credits have been used as an important alternative. Group lending has been reported to have positive contributions to the creditworthiness of borrowers and prevents problems of moral hazards and adverse selections (Armendariz and Morduch, 2005; Kah et al, 2005).

The high cost of delivering financial services to small and widely dispersed customers as well as difficult financial terrain in rural settings characterized by high covariant risks, missing markets for risk management instruments and lack of suitable collateral (Onumah, 2002; Masanjala, 2004) are some of the challenges that rural financial institutions encounter in their attempts to provide credit to rural dwellers especially women. Besides, the traditional criteria for borrowing are difficult to meet particularly by farmers, and women for that matter, thereby limiting their access to credit (FAO, 2000).

According to the World Bank Policy Research Report (2002), women continue to have systematically poorer command over a wide range of productive resources including land, information, education and more importantly financial services. Another constraint of the extent of access to credit is the failure of the management of microfinance institutions to properly consult beneficiaries before formulating their credit schemes (Martin et al, 2002). As such, borrowers and target clientele groups are often allowed to have very little or no influence over the design and implementation of projects geared towards improving their livelihoods. Also, financial institutions such as the rural banks tend to rely on already existing economic associations to identify suitable clients for credit advancement (FAO, 2002; Ayamga et al, 2006). This often leads to the exclusion of those individuals not in groups from having access to credit. Additionally, where the application procedures are long and complicated, access to credit is also limited especially in situations where many of the borrowers are illiterates (Johnson, 2004). Another key issue identified by some stakeholders in the credit markets is the use of harsh and coercive methods such as police and court threats by lenders to push for repayment and revision of the excessive interest rates (Business Week, 2005; The Financial Express, 2005).

To address the issue of the rural-urban divide in the provision of financial services in Ghana, the concept of rural banking started in the 1970s. The idea was conceived as a result of the fact that the traditional licensed banking institutions at the time were all structured, equipped and managed as citycentred institutions with their clients mostly in the export and import businesses as well as in the mining sector. This created the need to seek alternatives for the largely rural, non-business public who are also largely rural people, who were unbanked and outside of the commercial/investment banking system. It was critical to integrate the rural population into the banking system under rules and regulations designed to suit their socio-economic circumstances and the peculiarities of their occupation in farming and craft-making. As a result, the first rural bank was established in Ghana in 1976 at Nyakrom in the Agona District of the Central Region. The Naara Rural Bank with its headquarters at Paga in the Kassena/Nankana West District of the Upper East Region, which was established in 1981, was the first of its kind in northern Ghana.

Among other things, rural banks are expected to provide easy, flexible and accessible credit and other financial services to rural dwellers about 90 percent of whom depend largely on agriculture as their main source of livelihoods. Yet, the extent to which such people, particularly women in the Upper East Region of Ghana, access credit and related components of financial capital from the rural banks is not well known. The supply of credit to the rural folks who constitute about 84 percent of the population of the Upper East Region (Harold, 2005) is critical if the rural - urban divide characterized by high population drift to the urban centres is to be bridged. It is equally important to note that women constitute about 53 percent of the population of the Upper East Region (GSS, 2000) and any intervention aimed at alleviating poverty must of necessity integrate gender interests in the planning and implementation processes. Improving the extent of access to credit for low income households is a vital part of any rural development strategy, especially one designed to rectify long standing ruralurban as well as gender inequalities and to generate broad-based growth (Fleschner, 2000). For 
women farmers' access to financial resources such as credit to be improved therefore, policy makers must make conscious efforts to mainstream gender interests in their credit policy formulations.

In the context of this paper therefore, access to credit is defined as a situation in which an individual has the right to posses and make decisions regarding the use of funds in the short-term and to repay with interest at a time schedule that is convenient to both the borrower and lender. In this regard, anybody who does not attempt to get credit from formal, semi-formal/endogenous or informal/indigenous sources cannot be said to lack access nor have inadequate access. Thus, a person is said to lack access to credit if such a person makes efforts to acquire it without success. Similarly, a person is said to have inadequate access to credit if he or she applied for credit but is given such an amount that is insufficient to meet his or her credit need. Within the framework of the above contextual definitions, this paper examines the extent to which women farmers in the Upper East Region of Ghana are able to access credit from the rural banks to finance their farming activities and the factors that prohibit them or otherwise from doing so.

\section{Study Area and the Survey}

The survey was conducted in the Upper East Region of Ghana which covers a total land area of about 8,848 square kilometres $\left(\mathrm{km}^{2}\right)$, which forms about 3 per cent of Ghana's total land area. The Upper East Region lies within $10^{0} 45^{1} \mathrm{~N}$ and $0^{0} 45^{1} \mathrm{~W}$. The Region is bordered to the North by Burkina Faso, to the East by the Republic of Togo, to the South by Northern and to the West by the Upper West regions of the Republic of Ghana. Its administrative capital is Bolgatanga. Demographically, the Region has a total population of about 914,016 (GSS, 2000). Out of this, 484, 428 representing 53 percent are females with the remaining 429, 588 representing 47 percent being males. It is made up of nine (9) administrative districts and municipalities.

There are five (5) rural banks in the Region and four (4) of them were studied. The four rural banks studied include the BESSFA Rural Bank with its headquarters at Garu in the GaruTempane District, the Toende Rural Bank with its headquarters at Zebilla in the Bawku West District, the Naara Rural Bank with its headquarters at Paga in the Kassena-Nankana West District and the Builsa Community Rural Bank with its headquarters at Sandema in the Builsa District. The BESSFA Rural Bank has branches at Pusiga and Bawku as well as a mobilization centre at Nankpanduri. The Toende Rural Bank has a mobilization centre at Bazua. The Naara Rural Bank has branches at Navrongo, Sirigu, Bukere/Bolga and a mobilization centre at Chiana. The Builsa Community Rural Bank has a branch at Bolga.

Two hundred (200) women farmers including 50 from each District where the four rural banks studied have their headquarters were randomly sampled for the study. Out of the 200 women farmers sampled, 123 of them representing about 62 percent applied for credit from the rural banks and the remaining 77 of them representing about 38 percent did not apply for credit. Out of the 123 respondents who applied for credit, 100 of them representing about 81 percent were successful in their applications and 23 of them representing about 19 percent being unsuccessful. Fig. I below describes the sampling process.

\section{Figure 1: The Sampling Framework}




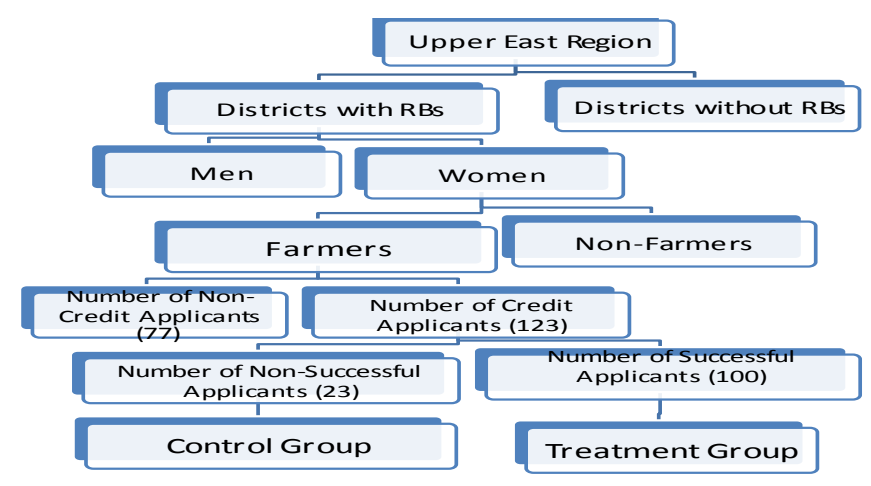

Source: Authors' Conceptualisation

\section{The Theoretical Framework}

The Tobit Model, which was developed by Tobin (1958), has been used by a number of researchers including Oladele (2005) and Dankyi et al (2005) in various related studies. According to Greene (2003) and Cameron and Trivedi (2005), if we assume that $Y_{\mathrm{i}}$ is the intensity of accessing a facility, in this case credit from the rural banks by women farmers, $p^{*}$ is a non-observable latent variable and $\mathrm{T}$ is a non-observed threshold level, then:

$$
\begin{array}{ll}
Y_{i}=X_{i} \beta & \text { if } p^{*}=X_{i} \beta+\varepsilon_{i}>T, \\
Y_{i}=0 & \text { if } p^{*}=X_{i} \beta+\varepsilon_{i} \leq T
\end{array}
$$

$X_{i}$ is a set of explanatory variables and $\varepsilon_{i}$ is assumed to be homoscedastic (i.e. independently and normally distributed stochastic term with zero mean, $\mu$ and constant variance, $\sigma^{2}$ ). If there is a perceived utility, $U(p)$ from making the decision to do something, say to borrow from rural banks and a utility $U(0)$ for not making that decision, say not borrowing from rural banks and there is a cluster of the population with no decision to make at the limit (BaiduForson, 1999; Oladele, 2005; Dankyi et al, 2005), then:

$$
\begin{aligned}
& P_{i}=X_{i} \beta+\varepsilon_{i} \\
& \begin{array}{l}
\text { if } X_{i}+\varepsilon_{i}>0, \text { positive unobserved latent var iable } \\
\text { Where: } U\left(X_{i 0}\right)>U\left(X_{i p}\right)
\end{array} \\
& \text { if } X_{i}+\varepsilon_{i} \leq 0 \text { in case of decison against } p
\end{aligned}
$$

$i=1,2,3, \ldots \mathrm{n}$ denotes the sample size surveyed; $p_{i}$ is the dependent variable (Proportion of Credit Accessed $=$ Credit Received $\div$ Credit Applied for $) ; X_{\mathrm{i}}$ represents the vector of independent variables categorized as socio-economic, technical and institutional factors; $\beta$ is a vector of unknown parameters to be estimated. The expected intensity of access to credit from rural banks by women farmers $\mathrm{E}(\mathrm{p})$ is given as follows:

$$
E(p)=X_{i} \beta F(z)+o f(z)
$$

Where $\mathrm{X}$ is the vector of the explanatory variables; $\mathrm{F}(\mathrm{z})$ is the cumulative normal distribution of $\mathrm{z} ; \mathrm{f}(\mathrm{z})$ is the value of the derivative of the normal curve at a given point (i.e. the unit normal distribution); $\mathrm{z}$ is the $\mathrm{Z}$-score for the area under the normal curve, given as $\mathrm{z}=X \beta / \sigma$; $\beta$ is a vector of tobit maximum likelihood estimates; and $\sigma$ is the standard error of the error 
term. The relationship between the expected value of all observations, $E_{p}$ and the expected conditional value above the limit $E_{p} *$ is given by:

$$
E_{p}=F(z) E_{p}^{*}
$$

Analyzing the policy implications of changes in the relevant explanatory variables that significantly influence the extent of credit access is a major component of this study. To this end, the effect of the $k^{\text {th }}$ variable of $\mathrm{X}$ on $p$ leads to the following decomposition:

$\delta E_{p} / \delta X_{k}=F(z)\left(\delta E_{p}^{*} / \delta X_{k}\right)+E_{p}^{*}\left(F(z) / \delta X_{k}\right)$

For the index or unobserved latent variable, the marginal effect of the censured regression or tobit model is calculated as (Greene, 2003: 764):

$$
\frac{\delta E\left(p^{*} \mid X_{i}\right)}{\delta X_{i}}=\beta
$$

However, the above marginal effect is of no interest in this paper because that variable is not observed and cannot be used for policy recommendations. To obtain the marginal effect of the observed variable that is of interest in this paper, the following formula (Greene, 2003: $765)$ is used:

$$
\frac{\delta E\left(p \mid X_{i}\right)}{\delta X_{i}}=\beta^{*} \operatorname{prob}\left(0<p^{*}<1\right)
$$

According to Greene (2003: 767), the log-likelihood of the tobit model is specified as:

$$
\ln L=\sum_{y i>0}-1 / 2\left[\log (2 \pi)+\ln \sigma^{2}+\left(y_{i}-x_{i}^{\prime} \beta\right)^{2} / \sigma^{2}\right]+\sum_{y i=0} \ln \left[1-\emptyset\left(x_{i}^{\prime} \beta\right) / \sigma\right]
$$

Maximizing this likelihood function with respect to $\beta$ and $\sigma$ gives the maximum likelihood estimates of these parameters. The truncated tobit model was employed because the seventyseven (77) respondents who did not attempt borrowing from the rural banks had to be left out of the estimation process. The Econometric Views (E-Views) Version 3.1 software was employed to estimate the parameters by MLE. The empirical specification of the tobit model is as follows:

$\operatorname{prob}\left(\frac{\text { Credit Received }}{\text { Credit Applied for }}\right)=f\left(Y_{1}, Y_{2}, Y_{3}, Y_{4}, Y_{5}, Y_{6}, Y_{7}, Y_{8}, Y_{9}, Y_{10}, Y_{11}, Y_{12}, Y_{13}, Y_{14}\right)$

See Table 1 below:

Table 1: Variables and their Mode of Measurements

\begin{tabular}{|l|l|}
\hline Dependent Variable & Mode of Measurement \\
\hline Proportion of Credit Accessed & Credit Received $\div$ Credit Applied for \\
\hline Independent Variables & Mode of Measurement \\
\hline Age of respondent $\left(\mathrm{Y}_{1}\right)$ & Years \\
Farm size $\left(\mathrm{Y}_{2}\right)$ & Hectares \\
Knowledge of credit sources $\left(\mathrm{Y}_{3}\right)$ & Binary (Knowledgeable $=1$; Otherwise $=0)$ \\
Perception of income level $\left(\mathrm{Y}_{4}\right)$ & Binary (High income level $=1 ;$ Otherwise $=0)$ \\
Perception of gender $\left(\mathrm{Y}_{5}\right)$ & Binary (Woman $=1$; Otherwise =0) \\
Years of formal schooling $\left(\mathrm{Y}_{6}\right)$ & Years \\
Association membership $\left(\mathrm{Y}_{7}\right)$ & Binary (Member $=1$; Otherwise = 0$)$ \\
\hline
\end{tabular}




\begin{tabular}{|l|l|}
\hline Savings $\left(\mathrm{Y}_{8}\right)$ & Binary (Have savings $=1 ;$ Otherwise $=0)$ \\
Type of crop grown $\left(\mathrm{Y}_{9}\right)$ & Binary (Cash crop = $1 ;$ Otherwise =0) \\
Perception of interest rate $\left(\mathrm{Y}_{10}\right)$ & Binary (Interest rate high $=1 ;$ Otherwise =0) \\
Distance to credit institution $\left(\mathrm{Y}_{11}\right)$ & Kilometres \\
Application procedures $\left(\mathrm{Y}_{12}\right)$ & Binary (Cumbersome = 1 ; Otherwise =0) \\
Access to farm land $\left(\mathrm{Y}_{13}\right)$ & Binary (Have access =1; Otherwise =0) \\
\hline
\end{tabular}

Source: Authors' Conceptualisation

\section{Choice of Variables and A Priori Expectations}

The variable selection was based more on literature and related studies by other researchers such as Nathan et al (2004), Ayamga et al (2006) and Fakayode and Rahji, (2009). The age of women farmers $\left(\mathrm{Y}_{1}\right)$ was included in the model as a proxy for maturity and the potential ability to utilize and repay credit by borrowers (Fakayode and Rahji, 2009). Age was expected to have a positive influence on the extent of access to credit. The farm size $\left(\mathrm{Y}_{2}\right)$ was also included as an estimate of the potential income of the borrower. The farm size was measured in hectares and expected to influence positively the extent of credit access because the larger the farm size, the higher the amount of credit the person was likely to apply for, ceteris paribus. Also, the more knowledgeable women farmers are $\left(\mathrm{Y}_{3}\right)$ on the different sources of credit to them, the higher their extent of access. This was expected to influence positively the intensity of access to credit by women farmers. The perception of women farmers that only high income earners can borrow from the rural banks $\left(\mathrm{Y}_{4}\right)$ was expected to have a negative influence on the intensity of access to credit. Also, the perception of women farmers that being a woman makes one unable to borrow a higher amount of credit from the rural banks $\left(\mathrm{Y}_{5}\right)$ was expected to have a negative effect on intensity of access. The number of years of formal schooling attained by women farmers $\left(\mathrm{Y}_{6}\right)$ was expected to have a positive effect on their extent of access to credit from the rural banks. See Table 1 below. This is because education is said to be a major factor that influences the decision to participate in and access credit (Ayamga et al, 2006; Lukytawati, 2009).

Membership to economic associations $\left(\mathrm{Y}_{7}\right)$ is a fundamental requirement for accessing credit by small borrowers (Egyir, 2008; Lukytawati, 2009) because group based lending is a way of circumventing adverse selection and moral hazard issues (Armendariz and Morduch, 2005). This was expected to have a positive effect on the extent of access to credit by women farmers because the rural banks rely on social collateral provided by such associations for the advancement of credit. This implies that once a person belongs to an economic association such a person is not required to provide collateral to be able to access credit. Members of the group jointly guarantee for each other.

Savings $\left(\mathrm{Y}_{8}\right)$ was also chosen because it served as a proxy for the measurement of the net worth of the farmer. The more savings made by the farmer, the more the likelihood of his or her ability to repay and therefore can be given credit. The type of crop grown $\left(\mathrm{Y}_{9}\right)$ was expected to have positive effects on the extent of access. This implies farmers in cash crop production were more likely to have higher access than those into food crop production. The higher the perception of women farmers that interest rate is high $\left(\mathrm{Y}_{10}\right)$, the lower their probability of access to credit. This was supposed to have a negative effect on the intensity of access. Distance $\left(\mathrm{Y}_{11}\right)$ was expected to have a negative effect on intensity of access implying that those who are far away from the banks will have lesser intensity of access than those who are close by. The perception of the application procedures $\left(\mathrm{Y}_{12}\right)$ was expected to have a negative effect on the extent of access to credit. The more difficult it is for women farmers to access land for farming $\left(\mathrm{Y}_{13}\right)$, the lesser their extent of access. As women farmers grow passed their economically active age $\left(\mathrm{Y}_{14}\right)$, the less their extent of access to credit.

\section{RESULTS AND DISCUSSIONS}

\section{Analyses of Growth Rates of Credit Supply by RBs in Upper East Region}


The study results revealed that the overall growth rate of credit supply by the rural banks in the Upper East Region of Ghana from 1998 to 2007 has been about 18 percent per annum (Figure 2). This implies that the supply of credit by the rural banks to their customers who comprise farmers and non- farmers as well as men and women continue to experience consistent positive growth for the ten-year period (1998-2007) covered in this study. See Fig 2 below.

\section{Figure 2: Growth rate of credit supply by RBs in Upper East region}

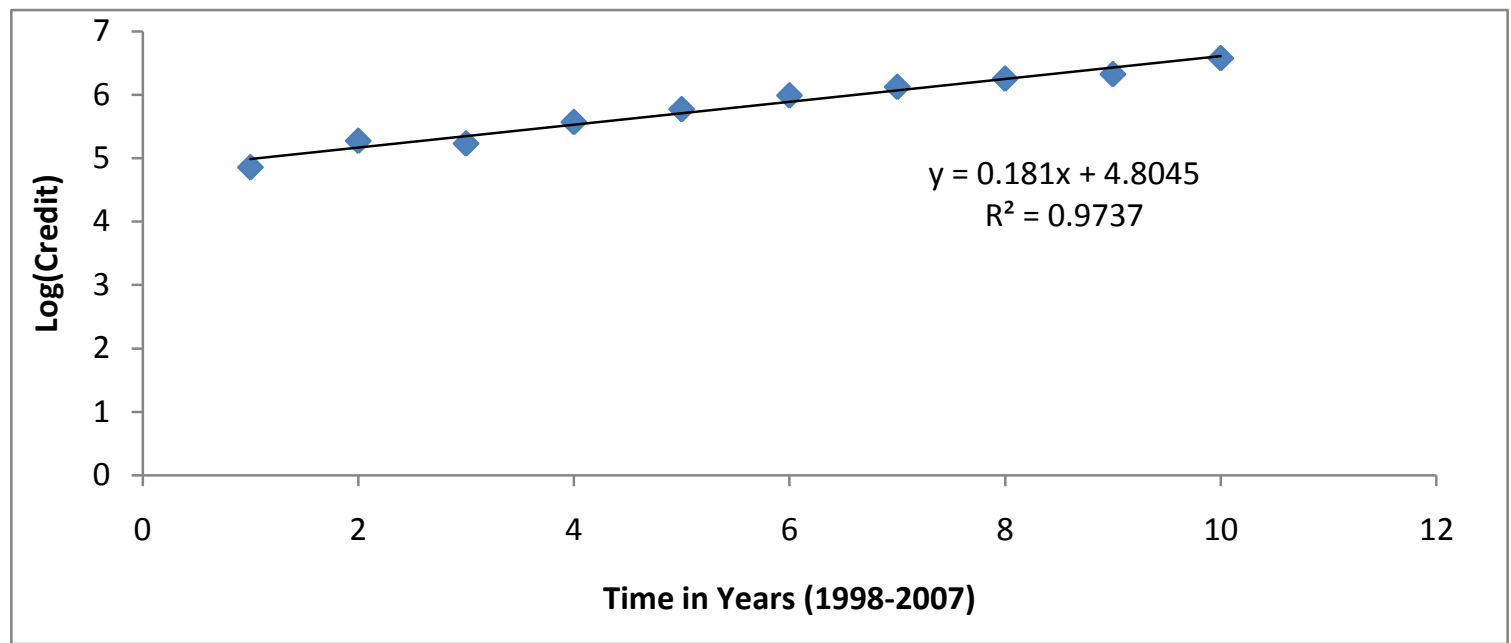

Source: Survey Data (Archives of RBs), 2008

The study results further revealed that the growth rate of credit supply to farmers by the rural banks in the Upper East Region from 1998 to 2007 has been about 0.16 (Figure 3). This implies that the supply of credit by rural banks to people engaged in farming in the Upper East Region grew at a positive rate of about 16 percent per annum during the period (1998 2007).

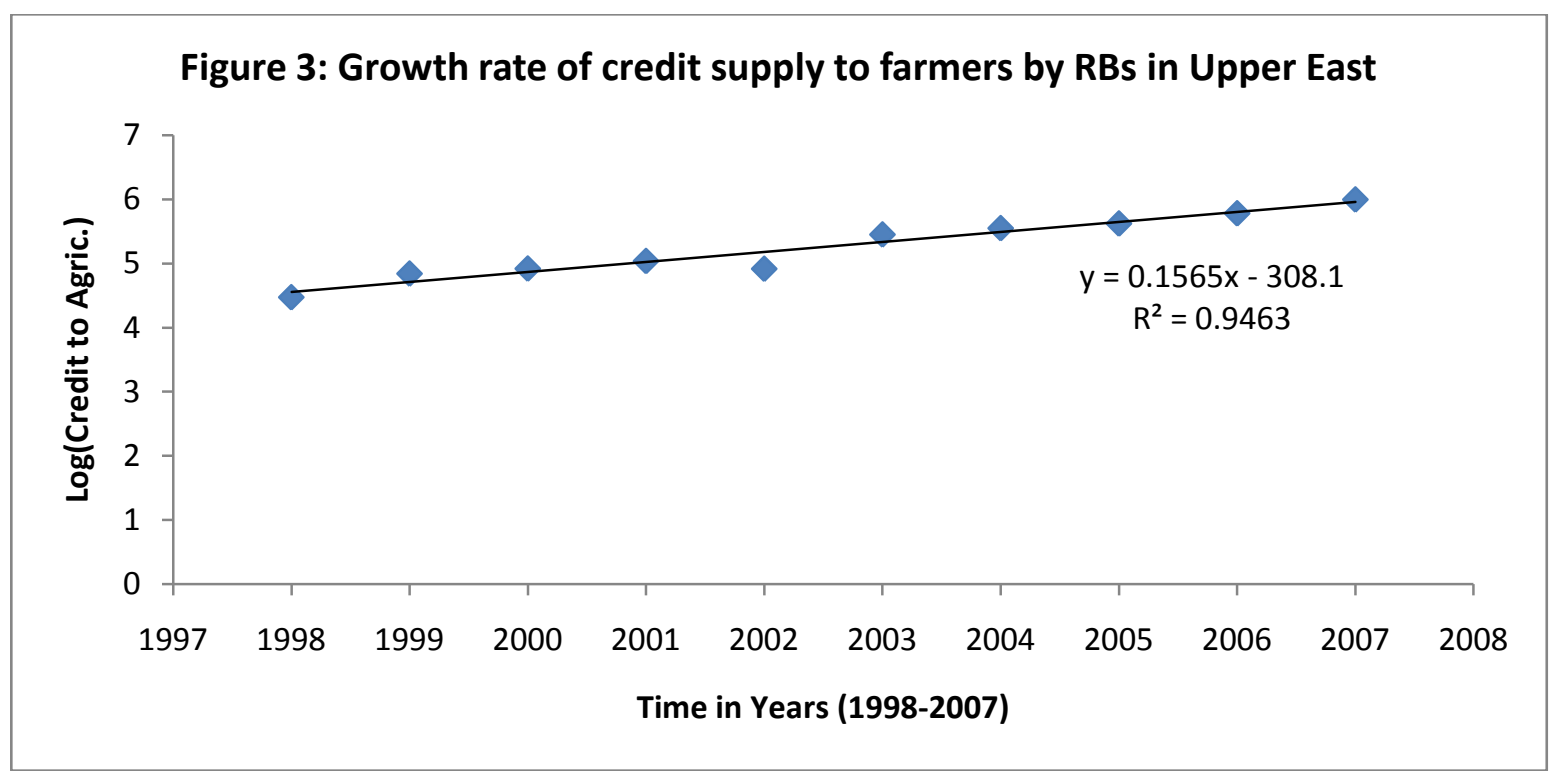

Source: Survey Data (Archives of RBs), 2008 
On the other hand, the growth rate of credit supply to non-farmers (transport owners, provision stores' keepers, government workers, etc.) by the rural banks for the same period (1998-2007) was found to be positive and is about 0.19 (Figure 4). This means that the annual growth rate of credit supply by the rural banks to the people engaged in non-farming activities in the Upper East Region from 1998 to 2007 was about 19 percent. A comparison of the growth rates of supply of credit to the farmers and non-farmers by the rural banks revealed that people in non-farm businesses experienced higher growth rate (about 3\%) than that of the farmers during the period (1998-2007).

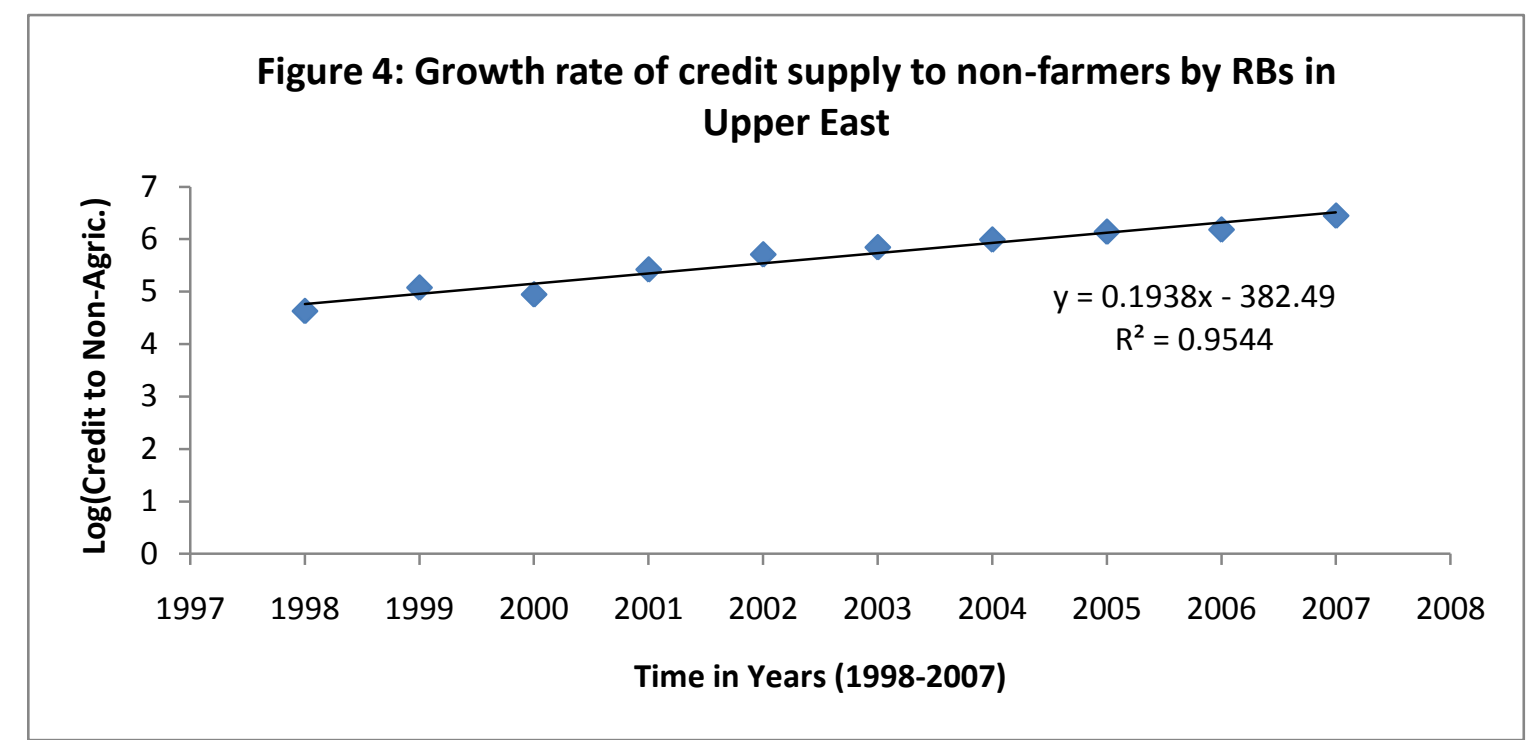

Source: Survey Data (Archives of RBs), 2008

Also, a general gender analysis showed that the growth rate of credit supply by the rural banks to men from 1998 to 2007 was about 0.19 (Figure 5) and that of women was about 0.18 (Figure 6). The implication here is that whereas the credit supply to men by the rural banks grew positively at about 19 percent per annum during the period $(1998-2007)$ that of the women grew at about 18 percent per annum at the same period.

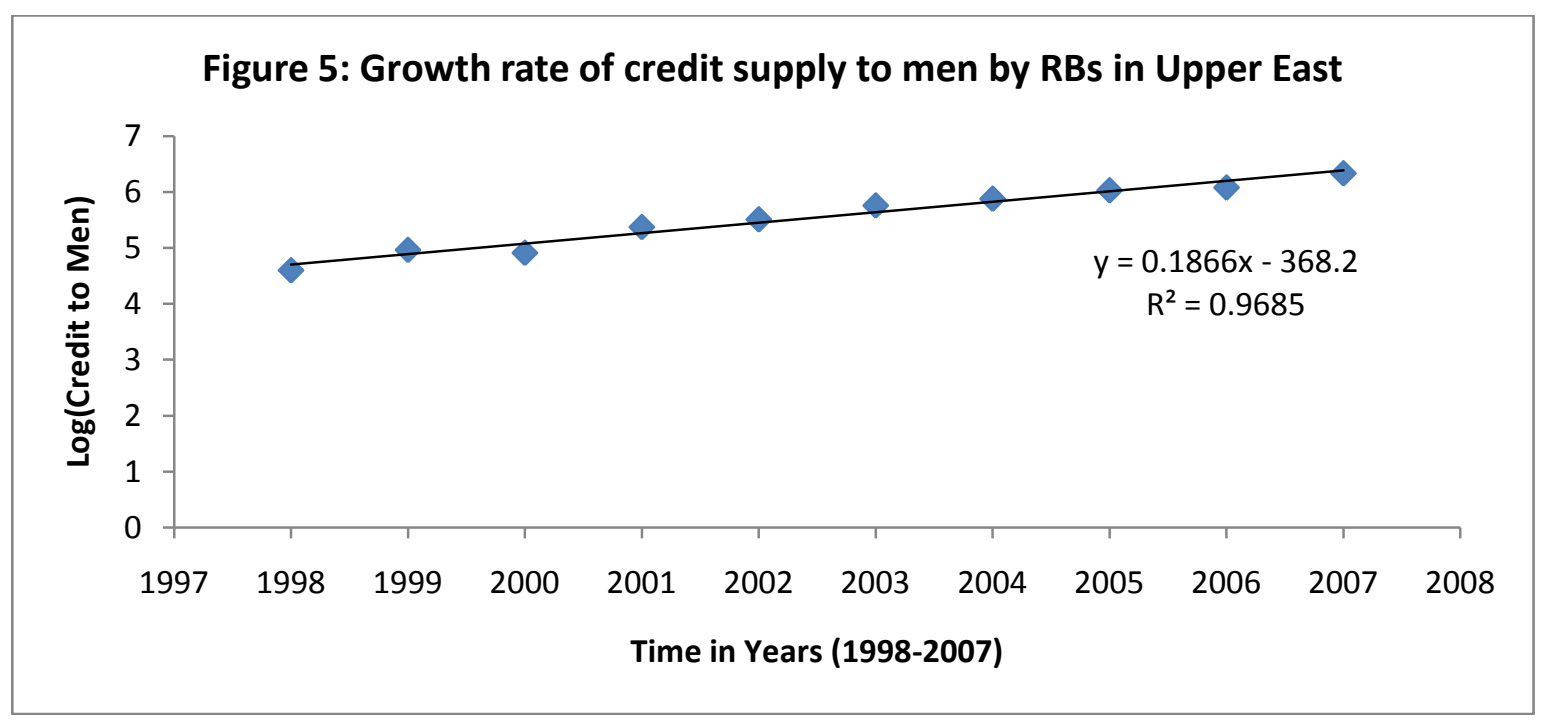


The results showed close gender parity between men and women in terms of the growth rate of credit supply by rural banks in the Upper East Region during the period (1998-2007). The fact that the annual growth rate of credit supply to men was about 1 percent higher than that of women shows that some efforts must be made to bridge the gap. Bridging the gap in the growth rates of credit supply between men and women by rural banks in the Upper East Region of Ghana is critical if the poverty levels especially among women are to be reduced.

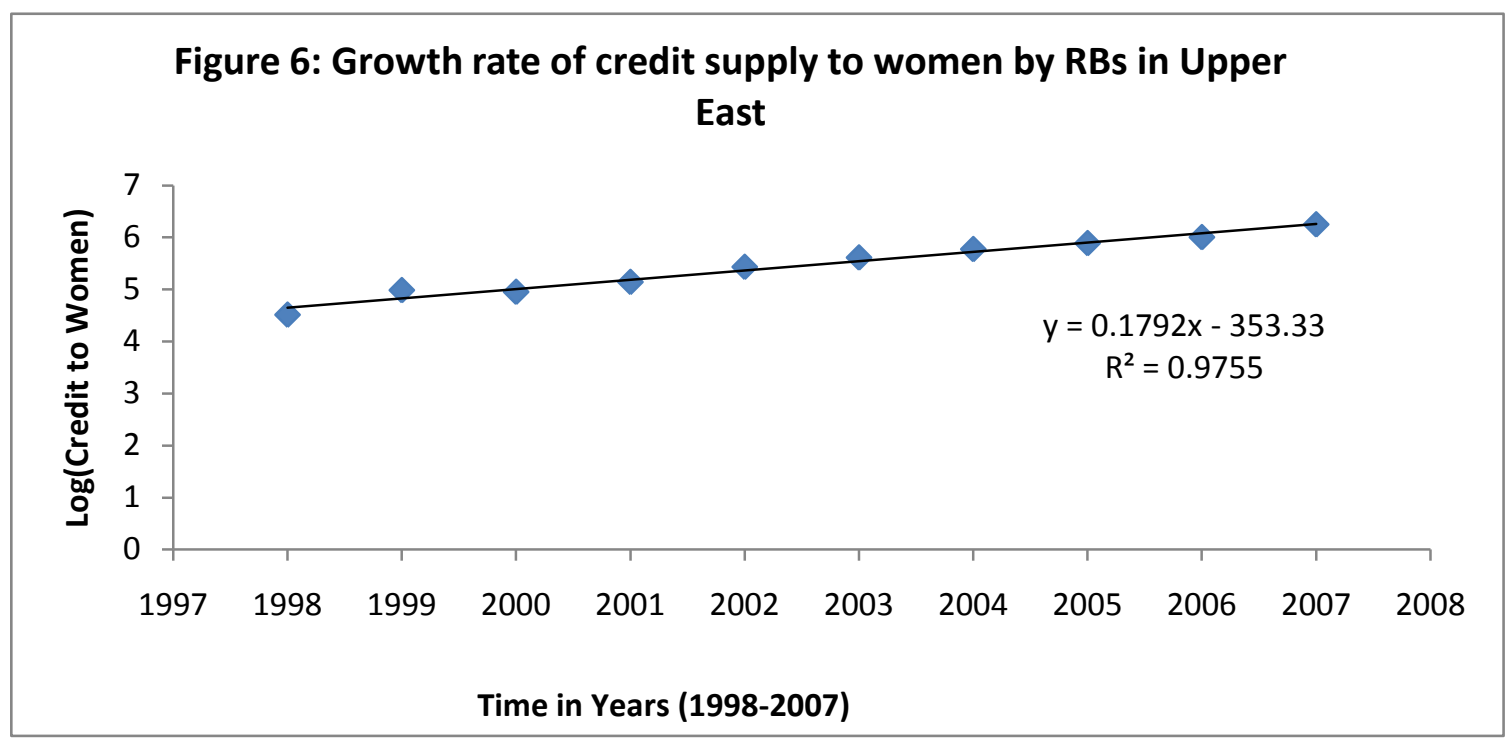

Source: Survey Data (Archives of RBs), 2008

Besides, gender analyses by categories (farmers and non-farmers) showed that the growth rate of credit supply to male farmers by the rural banks in Upper East Region from 1998 to 2007 was about 0.15 (Figure 7). This implies that the supply of credit to men farmers by the rural banks grew at about 15 percent annually during the period $(1998-2007)$. On the other hand, the results showed that the annual growth rate of credit supply to female farmers by the rural banks also grew positively at about 0.17 (Figure 8) at the same period (1998-2007).

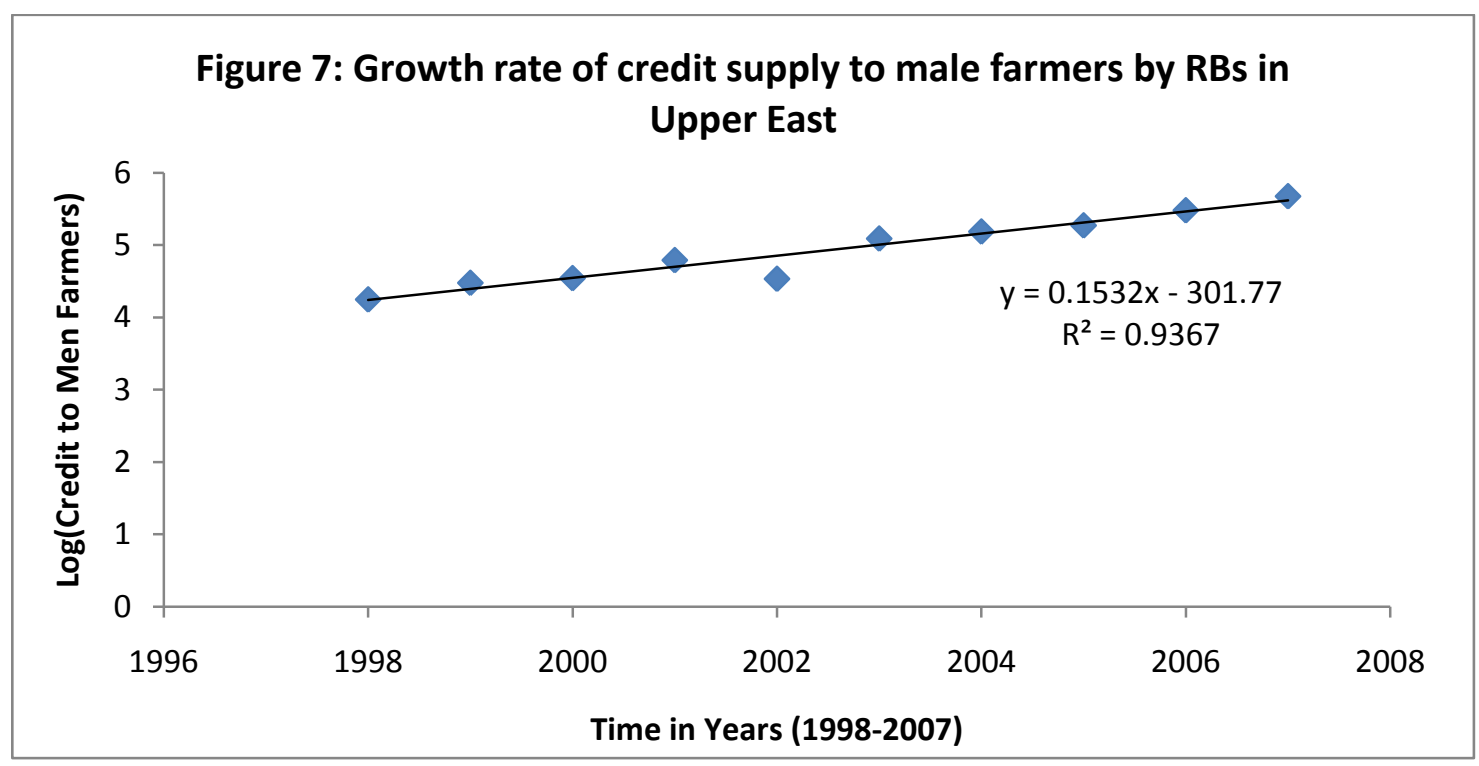


A comparison of the growth rates of credit supply by rural banks to male and female farmers (Figure 7 and Figure 8 ) shows a difference of 2 percent in favour of the female farmers. This difference in growth rate of credit supply to female farmers though may appear to be marginal, it cannot be underestimated. The fact that the annual growth rate of credit supply to female farmers by the rural banks in the Upper East Region is higher (about 2\%) than that of their male counterparts is recommendable. The desparity of growth rates of credit supply between male and female farmers though close is critical given that women who are more vulnerable constitute about 53 percent of the pupolation of the Upper East Region (GSS, 2000) and that about 90 percent of them depend on farming for their livelihoods.

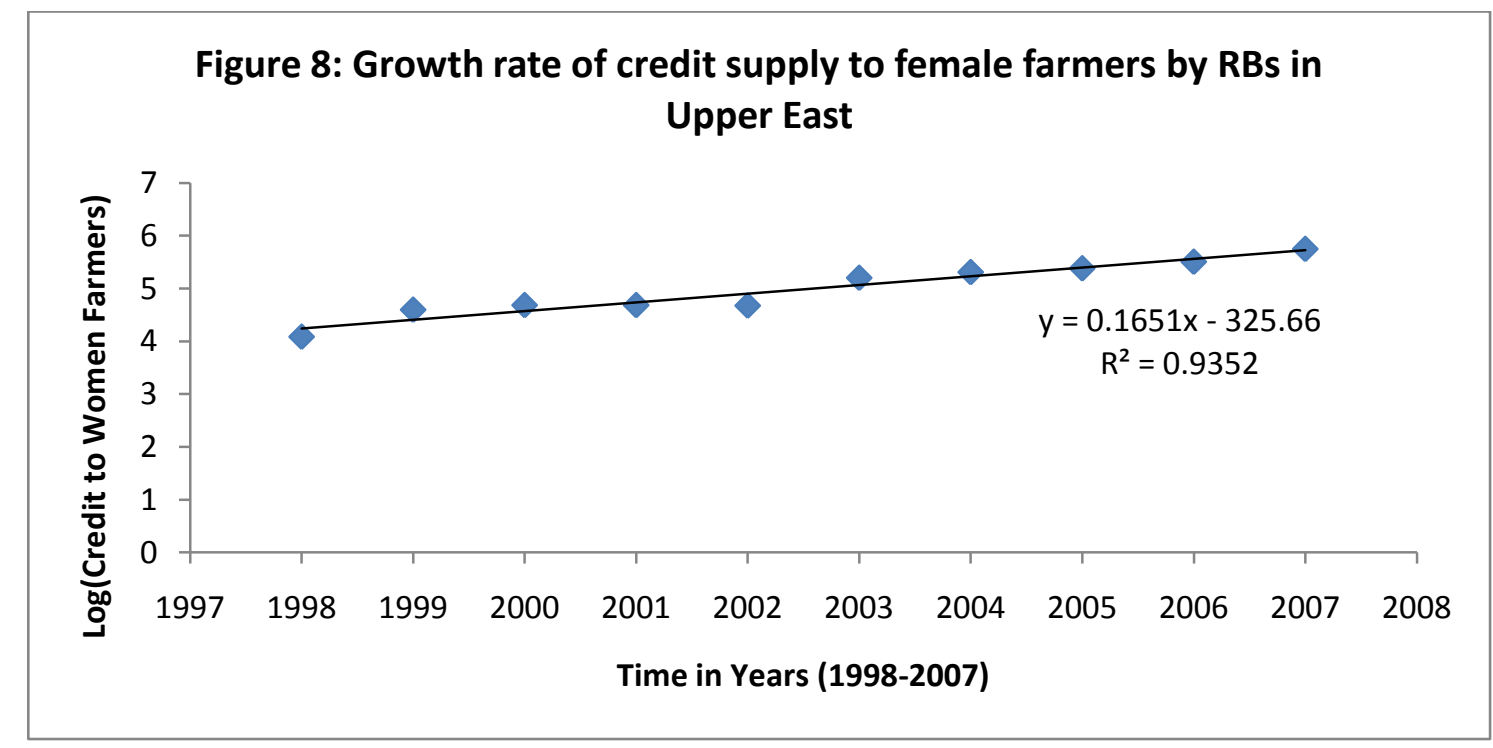

Source: Survey Data (Archives of RBs), 2008

In the case of gender analyses of credit supply to non-farmers, the results showed that the annual growth rate of credit supply to male non-farmers from 1998 to 2007 was about 0.20 (Figure 9) and that of their female counterparts was about 0.19 (Figure 10). 


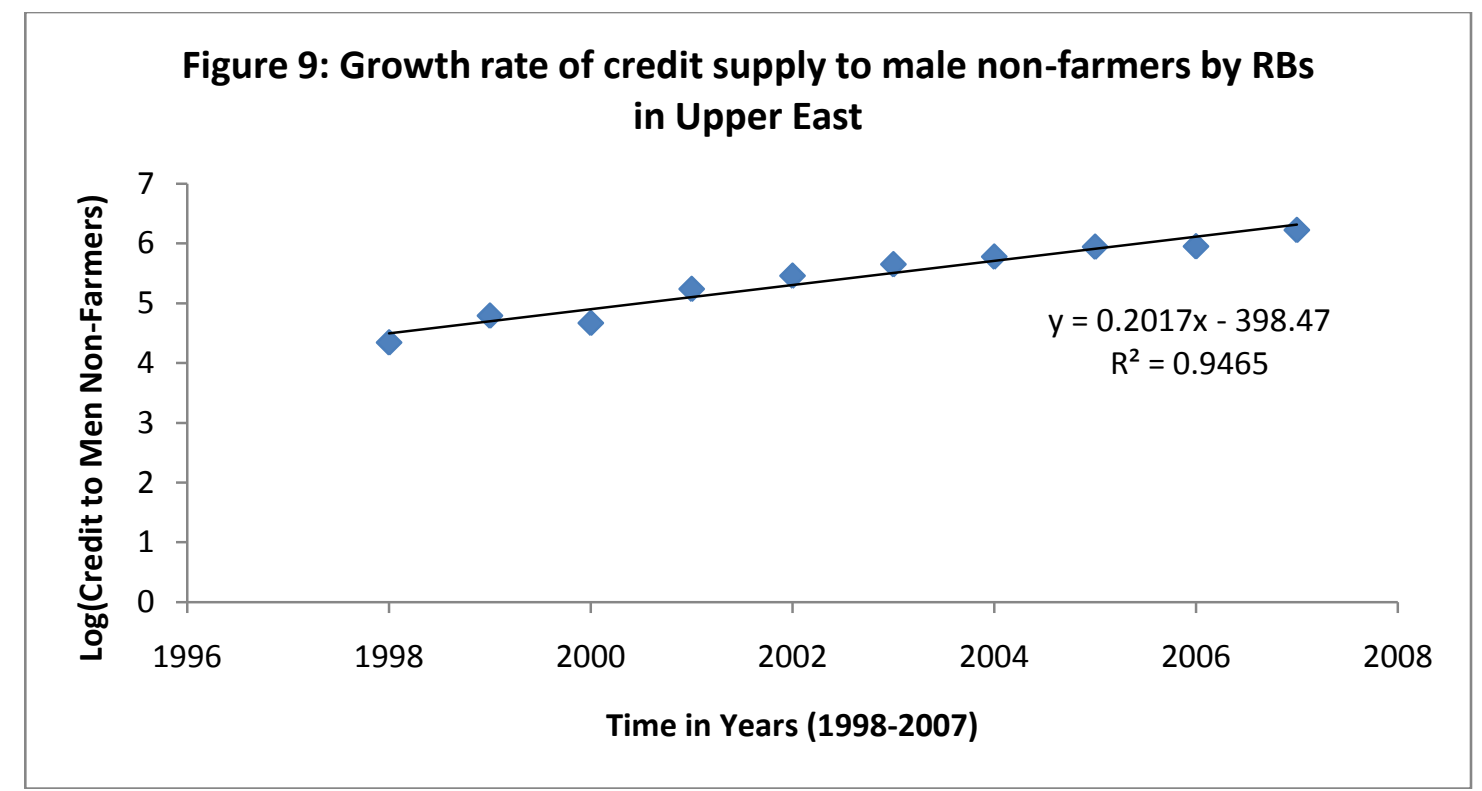

Source: Survey Data (Archives of RBs), 2008

The implication of the finding is that the supply of credit to male non-farmers including provision stores' keepers, transport operators, government workers and drinking bar operators among others grew positively at about 20 percent per annum from 1998 to 2007 and that of their female counterparts grew at about 19 percent per annum during the same period. The a comparison of the growth rates of credit supply to male and female non-farmers gave a difference of about 1 percent. This shows a close gender parity which should be strengthened and sustained.

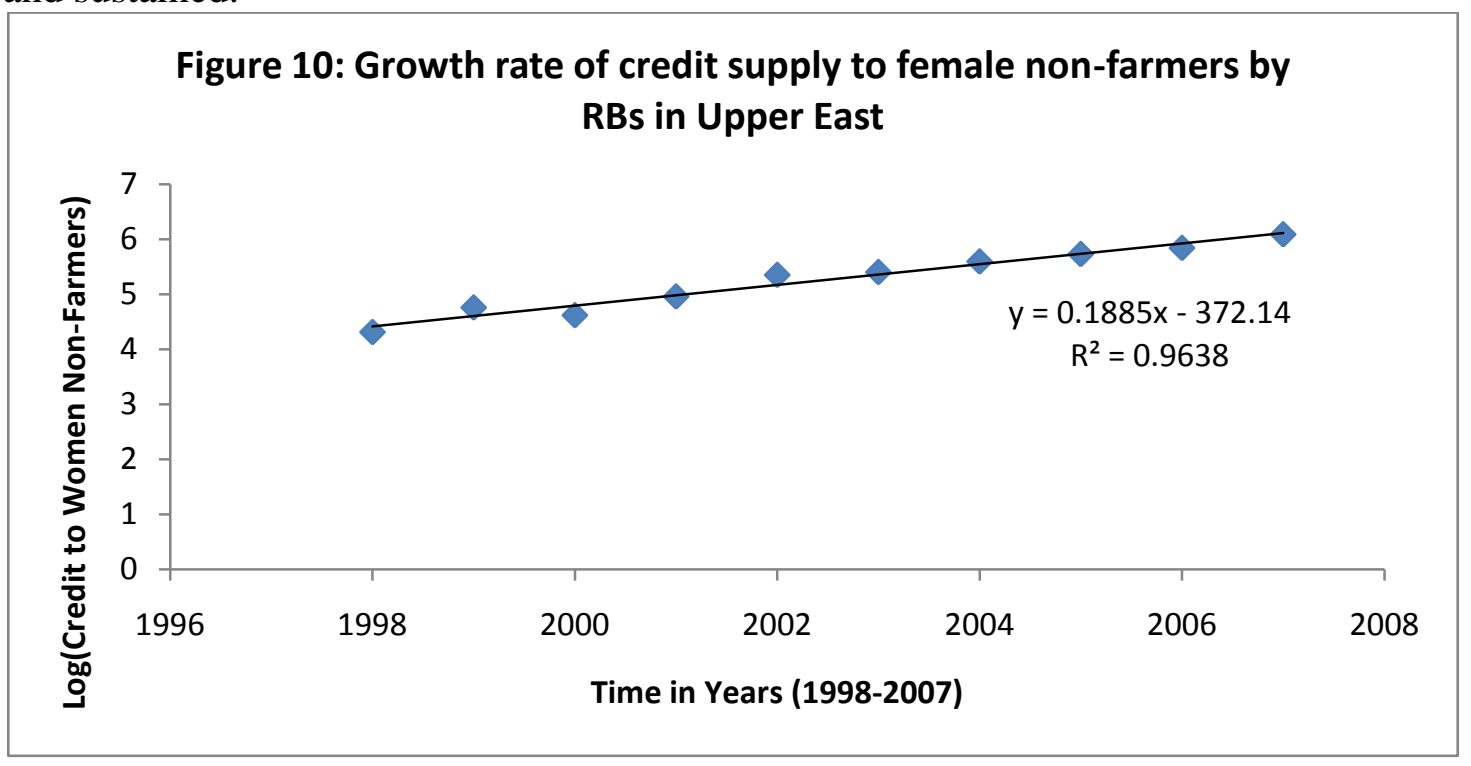

Source: Survey Data (Archives of RBs), 2008

\section{Factors Influencing the Women Farmers Access to Credit}

To determine the factors influencing the extent to which women farmers are able to access credit from the rural banks in the Upper East Region of Ghana, the truncated tobit model was used. The truncation was as a result of the fact that those respondents who did not attempt to 
apply for credit from the rural banks were excluded from the tobit model estimation. The tobit regression results gave an adjusted $\mathrm{R}$ - squared of about 0.67 which implies that all the explanatory variables included in the model are able to explain about 67 percent of the variability in the extent of access to credit from the rural banks by women farmers. Giving the goodness of fit measure (adjusted R-squared), it can be concluded that the tobit model used has integrity and the requisite explanatory power.

Table 2: Tobit regression results of factors influencing extent of access to credit from rural banks by women farmers in Upper East

\begin{tabular}{|c|c|c|c|}
\hline Variable & Coefficient & Standard Error & $\begin{array}{l}\text { Marginal } \\
\text { Effects }\end{array}$ \\
\hline $\begin{array}{l}\text { Constant } \\
\text { Age } \\
\text { Age squared } \\
\text { Perception of application procedures } \\
\text { Membership to economic associations } \\
\text { Type of crop grown } \\
\text { Distance from respondents to banks } \\
\text { Years of formal schooling } \\
\text { Farm size } \\
\text { Knowledge of sources of credit } \\
\text { Perception of income level } \\
\text { Perception of interest charged } \\
\text { Access to land for farming } \\
\text { Savings made with rural banks } \\
\text { Perception of gender }\end{array}$ & $\begin{array}{l}-1.189633 \\
0.032572 \\
-0.000343 \\
-0.037166 \\
0.203943 \\
0.319356 \\
-0.073818 \\
0.161758 \\
0.250963 \\
0.038881 \\
0.224932 \\
-0.212934 \\
0.104696 \\
0.180945 \\
0.147915\end{array}$ & $\begin{array}{l}0.430785 \\
0.019577 * \\
0.000224 \\
0.072043 \\
0.052673 * * * \\
0.058410^{* * *} \\
0.048249 \\
0.047928^{* * *} \\
0.048277^{* * *} \\
0.033884 \\
0.048955^{* * *} \\
0.061727 * \\
0.046262 \\
0.054840^{* * *} \\
0.053842 *\end{array}$ & $\begin{array}{l}- \\
0.0155 \\
- \\
- \\
0.0972 \\
0.1523 \\
- \\
0.0771 \\
0.2297 \\
- \\
0.1072 \\
-0.1015 \\
- \\
0.0862 \\
0.0705\end{array}$ \\
\hline \multicolumn{4}{|l|}{ Goodness of fit measures } \\
\hline \multicolumn{2}{|l|}{$\begin{array}{l}\text { R-squared } \\
\text { Adj. R-squared }\end{array}$} & \multicolumn{2}{|l|}{$\begin{array}{l}0.696206 \\
0.671440\end{array}$} \\
\hline
\end{tabular}

*** Significant at 1\%; ** Significant at 5\%; * Significant at $10 \%$

Source: Field Survey Data, 2008

Except the perceptions of income level and gender, all the included exogenous variables met the a priori expectations. The age of respondents, level of education, knowledge of credit sources, access to farm land, the perception of income level, perception of gender, the farm size, membership to economic associations, savings with rural banks and the type of crop grown (cash) are all positively related to the extent of access to credit from the rural banks by women farmers. Besides, age squared, perception of the application procedures (whether cumbersome or not), the perception of interest charged and the distance from respondents' residence to the rural banks were also found to be negatively related to the extent of access to credit from the rural banks.

From the tobit model regression results (Table 2), the age of women farmers positively influence their extent of access to credit from the rural banks and was found to be significant at $10 \%$. Age was also found to assume a quadratic function implying that as women farmers advance in age, their intensity of access to credit increases up to a certain age and then starts to decline. Association membership was found to be significant at $1 \%$. If a woman farmer joins an economic association, the amount of credit that she can access from the rural bank will increase by about 0.10 units. Types of crops grown (cash crop or otherwise) were also found to be significant at $5 \%$. If a woman farmer goes into the cultivation of cash crops such 
as groundnut, soybeans, rice and onions among others, then the amount of credit that she can access from the rural bank will increase by about 0.15 units. Similarly, formal education was found to be significant at $1 \%$. If a woman farmer gets an extra year of formal education, the amount of credit she can access from the rural bank(s) is increased by about 0.08 units. In addition, farm size was found to be significant at $1 \%$. An extra hectare cultivated by a woman farmer will lead to 0.23 units increase in the average credit that she can take from the rural banks.

Furthermore, perception of income level was found to be significant at $1 \%$. If women farmers' perception that only high income earnings can access credit from the rural banks is changed, then the amount of credit that they can access will increase by about 0.11 units. In the same way, perception of interest charged was found to be significant at $10 \%$. If women farmers change their perception that interest rate charged by the rural banks is high, then the average amounts of credit that they can receive from the rural banks will be increased by about 0.10 units. Savings made by women farmers with the rural banks was found to be significant at $1 \%$. If women farmers increase their savings with the rural banks, then the mean amounts that they currently take will be increased by about 0.09 units. Finally, the perception of gender was found to be significant at $10 \%$. If women farmers change the perceptions that they cannot take large amounts of credit from the rural banks because they are women, then the average amounts they currently take will increase by about 0.07 units.

\section{SUMMARY AND CONCLUSION}

The study results showed that about 81 percent of women farmers who apply for credit from the rural banks in the Upper East Region of Ghana were successful in their credit applications. The study results also revealed that the supply of credit by the rural banks in the region (Upper East) to their customers who are farmers grew at an average of about 16 percent per annum from 1998 to 2007 and that of non-farmers grew at about 19 percent per annum at the same period. In terms of gender, the average growth rate of credit supply to men by the rural banks during the period (1998-2007) was about 19 percent per annum and that of women was about 18 percent per annum. Further gender analyses by categories (farmers and non-farmers) showed that the average growth rate of credit supply by the rural banks in the Upper East Region to male farmers from 1998 to 2007 was about 15 percent per annum and that of their female counterparts was about 17 percent per annum during the same period. Whereas men in the non-farming sector experienced an annual average growth rate of about 20 percent (the highest growth rate recorded) during the period (1998-2007), their women counterparts experienced a corresponding credit supply growth rate of about 19 percent per annum.

The study further indicated that socio-economic factors such as age, membership to economic associations, the type of crop grown (cash or food), level of formal education, farm size, perception of income levels, savings made with the rural banks and being a woman (perception of gender) greatly influence women farmers' extent of access to credit from the rural banks in the Upper East Region of Ghana. Besides, one of the technical factors that negatively influences women farmers' extent of access to credit from the rural banks is the interest rates charged by the banks which they (women farmers) perceived are way too high. It is therefore concluded that a high percentage (81\%) of women farmers who apply for credit from the rural banks in the Upper East Region are granted credit. The rural banks in the region (Upper East) from 1998 to 2007 recorded steady positive growth rates in their credit supply to customers across the different occupations and gender. The growth rates of credit 
supply by the rural banks during the period (1998-2007) generally favored customers who were engaged in non-farm businesses than those in farm businesses. As regards to gender, the growth rates recorded during the period were largely in favor of men. Subsequently, it can be concluded that the perception rather than the actual experiences of gender discrimination of women farmers in the Upper East Region regarding the operations and requirements of the rural banks influence their extent of access to credit.

\section{RECOMMENDATIONS}

Bases on the findings above, the following recommendations are made:

Firstly, there have been close gender parity and consistent positive growth rates of credit supply by the rural banks to men and women as well as famers and non-farmers. The rural banks are thus encouraged to improve and sustain the close gender parity in their operations.

Secondly, the perceptions of women farmers regarding the operations and requirements of the rural banks influence their extent of access to credit. It is therefore recommended that the rural banks in collaboration with the Extension Department of the Ministry of Food and Agriculture (MoFA) and the Non-Functional Literacy Division (NFLD) of the Ministry of Education (MoE) should come out with an educational package that will help disabuse all the misconceptions of women farmers regarding what the rural banks offer and who can access what is being offered. This will help strengthen and sustain the facilitating factors and mitigate that of the militating ones so as to improve their (women farmers) access to credit.

Thirdly, it is recommended that all women farmers endeavor to make some savings with the rural banks and to go into the production of cash crops such as soybeans, groundnut, rice and onions on reasonable farm sizes and join economic associations so as to improve their extent of access to credit, which is critical for the attainment of the MDGs on gender empowerment and equality as well as hunger and poverty reduction. 